\title{
O ROSYJSKOŚCI SYNTETYZMU PÓŁTORATONÓWKA
}

\author{
JAN WAWRZYŃCZYK \\ profesor emeritus \\ Uniwersytet Warszawski, Polska \\ e-mail: j.wawrzynczyk@uw.edu.pl \\ (nadesłano 4.11.2017; zaakceptowano 5.11.2017)
}

\begin{abstract}
The note is devoted to the history of the Polish word póttoratonówka. The question is raised about the beginning and extinction of its Russian connotation.
\end{abstract}

\section{Key words}

Russianism, univerbation, półtoratonówka, polutorka truck, translation.

\section{Резюме}

\section{О русскости универба póttoratonówka}

Заметка посвящена истории польского слова póltoratonówka. Ставится вопрос о зарождении и угасании его русской коннотации.

\section{Ключевые слова}

Русизм, универб, półtoratonówka, полуторка, полуторатонка, перевод.

Ten rzeczownik nie występuje w żadnym z podstawowych słowników ogólnych języka polskiego (od „Lindego” do „Dubisza”) ${ }^{1}$. Odnotowany został dopiero w jednym

1 Ich listę z dokładnymi danymi bibliograficznymi por. w: J. Wawrzyńczyk. 250 tysięcy ciekawych słów. Leksykon przypomnień. T. 1. Wyd. 2 poszerz. Warszawa: BEL Studio, 2016, s. 7. 
ze specjalnych opracowań leksykograficznych poświęconych tzw. nowemu słownictwu polskiemu ${ }^{2}$. W pracy tej wyraz został udokumentowany ${ }^{3}$ jednym jedynym cytatem z nieistniejącej dziś gazety „Sztandar Młodych”, wydawanej w Warszawie. Rozszerzona obserwacja polskich tekstów wydanych po II wojnie światowej, wykraczająca znacznie śmielej poza ten krąg publikacji prasowych i pozaprasowych, który ekscerpowany jest już od wielu lat przez samą Teresę Smółkowąa ${ }^{4}$, a następnie przez zespół pod jej kierunkiem, umożliwia zebranie innych świadectw bytowania rzeczownika półtoratonówka w języku polskim, świadectw starszych.

Najwcześniejsze świadectwa życia danego syntetyzmu, jakie mi się udało znaleźć, związane są mocno, jednoznacznie z rzeczywistością rosyjską i jej odzwierciedleniem w tekstach polskich, tłumaczonych i oryginalnych.

Charakterystyczne jest jego użycie przez Ferdynanda Goetla (pisarza o dorobku nader znaczącym dla relacji polsko-rosyjskich) w narracji osnutej na przekazie słów Rosjanina świadka zdarzeń w wiadomym lesie katyńskim:

W marcu 1940 pracowałem, jak zwykle, przy inspektach. Podczas pracy zauważyłem przejeż-

dżający drogą konwój samochodów. Najpierw samochód osobowy, później dwa wozy więzien-

ne, zamknięte i czarne, znane powszechnie pod nazwą „,czornyj woron”. Za nimi

półtoratonówka. ${ }^{5}$

Nie wiemy, jakiego słowa użył w rozmowie z Goetlem rosyjski informator, mogła to być полуторка albo полуторатонка. Pierwsze poświadcza na przykład Aleksander Sołżenicyn:

Но армии проснулись, пошли в наступление, - и Наде пришлось ехать домой - опять в той же неуклюжей гимнастерке, с тем же поддельным красноармейским билетом.

Полуторка увозила ее по лесной просеке, и она из кузова еще долго-долго махала ему. 6

Drugie słowo potwierdza m.in. Warłam Szałamow:

Мы вышли к машине. Полуторатонка с откинутым кузовом ${ }^{7}$.

Istotne jest, że zarówno tłumacz utworu Sołżenicyna, jak i tłumacz Szałamowa wygenerowali w procesie przekładu ten sam syntetyzm: póttoratonówka ${ }^{8}$.

2 Nowe słownictwo polskie. Materiały z prasy lat 1985-1992. Cz. 2: P-Ż. Red. T. Smółkowa. Kraków: Wydawnictwo IJP PAN, 1999.

3 Na s. 69. wyrazisty cytat posłużył zespołowi do sformułowania definicji: 'samochód ciężarowy, którego dopuszczalna ładowność wynosi półtorej tony’.

4 Por. T. Smółkowa. Nowe słownictwo polskie. Badania rzeczowników. Wrocław: Zakład Narodowy im. Ossolińskich, 1976.

5 Por. F. Goetel. Czasy wojny. Londyn: nakł. Katolickiego Ośrodka Wydawniczego „Veritas”, 1955, s. 262.

6 Por. А. Солженицын. Собрание сочинений в шести томах. Т. 3: В круге первом. Frankfurt/ Main: Посев, 1969, s. 283.

7 В. Шаламов. Собрание сочинений в шести томах. Т. 1. Москва: Терра - Книжный клуб, 2004, s. 191.

8 A. Sołżenicyn. Krąg pierwszy. Przeł. M. Kaniowski. Paryż: Instytut Literacki, 1970, s. 248; W. Szałamow. Opowiadania kołymskie. I: Pierwsza śmierć. Przeł. J. Baczyński. Gdańsk: Atex, 1991, s. 197. 
O trwałości tekstowej, o cyrkulacji derywatu półtoratonówka w świecie tekstów polskojęzycznych świadczy cytat z 9. (tak!) wydania polskiego znanej powieści B oкonax сталинграда':

Kapitan przychodzi o świcie. Za pięć minut ma tu być półtoratonówka - pojedziemy do fabryki traktorów.

Leksykalna nowość półtoratonówka nie została chyba odnotowana w pracy Jaworskiej o rusycyzmach ${ }^{10}$, zapewne z powodu jej nieobecności w słownikach języka polskiego.

Dla nosicieli polszczyzny, native speakerów, wciągniętych w orbitę kultury, literatury i języka rosyjskiego po 1945 roku, omawiany wyraz niewątpliwie miał konotację rosyjskości. Wraz z wygasaniem znaczenia języka rosyjskiego, związanym z zachodzącymi zmianami politycznymi, ta konotacja musiała z biegiem lat osłabnąć i w końcu zaniknąć. Równocześnie zaczęły się bowiem pojawiać liczne nowe związki wyrazowe z przymiotnikiem półtoratonowy, odnoszące się nie tylko do samochodów ciężarowych, lecz także do aut osobowych oraz innych obiektów o wyróżniającej się, ponadnormatywnej itp. wadze. Odpowiednich przykładów dostarczają dane Internetu. Od lat można w nim zobaczyć związki owego przymiotnika m.in. z rzeczownikami: ciało, ciagniki, cielsko, figury, kombi, ładunki, odważniki, ople, osobówki, płyty, zwierciadło, żarna i wielu, wielu innymi. Zwróćmy uwagę, że większości implikowanych tu analityzmów mogą odpowiadać w praktyce mownej, w spontanicznej komunikacji syntetyzmy: półtoratonowe ciało > półtoratonówka, półtoratonowe ciagniki > półtoratonówki, półtoratonowe cielsko > póttoratonówka itd. itp. Mówiący, nadawca komunikatu $\mathrm{z}$ reguły nie krępuje się tu homonimią, kłopot niejednoznaczności pozostawia odbiorcy.

Nie należy też zapominać, że przymiotnik póttoratonowy jest homofoniczny, ma w swej podstawie rzeczownik (1) tona i/albo (2) ton. Półtoratonowe są i dźwięki, stąd możliwa - co najmniej teoretycznie - póttoratonówka 'dźwięk, głos .... O zaistnieniu tego rodzaju bytów rozstrzygają zawsze konkretne potrzeby onomazjologiczne nadawcy.

\section{Bibliografia}

Goetel F. Czasy wojny. Londyn: nakł. Katolickiego Ośrodka Wydawniczego „Veritas”, 1955.

Niekrasow W. W okopach Stalingradu. Przekł. J. Jędrzejewicz. Wyd. 9. Warszawa: Czytelnik, 1966.

Nowe słownictwo polskie. Materiały z prasy lat 1985-1992. Cz. 2: P-Ż. Red. T. Smółkowa. Kraków:

Wydawnictwo IJP PAN, 1999.

Smółkowa T. Nowe słownictwo polskie. Badania rzeczowników. Wrocław: Zakład Narodowy im.

Ossolińskich, 1976.

Sołżenicyn A. Krag pierwszy. Przeł. M. Kaniowski. Paryż: Instytut Literacki, 1970.

9 W. Niekrasow. W okopach Stalingradu. Przekł. J. Jędrzejewicz. Wyd. 9. Warszawa: Czytelnik, 1966, s. 117.

10 Ю. Л. Яворская. Очерки по русско-польским языковым взаимодействиям. Szczecin: Wyższa Szkoła Pedagogiczna, 1983. W publikacji (bardzo trudno czytelnej reprodukcji maszynopisu) brak indeksu omówionych wyrazów. 
Szałamow W. Opowiadania kołymskie. I: Pierwsza śmierć. Przeł. J. Baczyński. Gdańsk: Atex, 1991. Wawrzyńczyk J. 250 tysięcy ciekawych słów. Leksykon przypomnień. T. 1. Wyd. 2 poszerz. Warszawa: BEL Studio, 2016.

Солженицын А. Собрание сочинений в шести томах. Т. 3: В круге первом. Frankfurt/Main: Посев, 1969.

Шаламов В. Собрание сочинений в шести томах. Т. 1. Москва: Терра - Книжный клуб, 2004.

Ю. Л. Яворская. Очерки по русско-польским языковым взаимодействиям. Szczecin: Wyższa Szkoła Pedagogiczna, 1983. 